\title{
Extensive dermatophytosis caused by Microsporum gypseum in an AIDS patient in Madras
}

\author{
S. Arun Mozhi Balajee ${ }^{*}$, Thangam Menon ${ }^{*}$, S. Ranganathan ${ }^{*}$, C.N. Deivanayagam ${ }^{\dagger}$, Kannan $^{\dagger}$, Mahilmaran $^{\dagger}$, \\ S. Ranganathan ${ }^{\dagger}$
}

\begin{abstract}
Abstrak
Tulisan ini melaporkan hasil isolasi Microsporum gypseum dari infeksi primer penderita AIDS. Lesi bersifat luas, non pustular dan non eritem. Lesi ini tidak menimbulkan rasa gatal, tapi menyebar ke seluruh tubuh dalam beberapa hari. Riwayat penyakit, hitung CD4 dan CD8 menunjukkan adanya gangguan imunitas. Diduga bahwa imunosupresi akibat infeksi HIV merupakan penyebab gambaran klinis yang khas ini.
\end{abstract}

\begin{abstract}
The present paper reports the isolation of a strain of Microsporum gypseum from a primary infection in an HIV patient. The lesion was extensive, non-erythematous and non-pustular. The lesion was devoid of itching and had spread throughout the body in a few days. Clinical history and CD4 and CD8 count of the patient suggested impaired immune status. Immunosuppression due to HIV infection would have caused the peculiar manifestation of the disease.
\end{abstract}

Keywords : Dermatophytosis, HIV infection, Immunosuppression

\section{INTRODUCTION}

Microsporum gypseum, a geophilic dermatophyte is reported to be prevalent in soil throughout the world. ${ }^{1}$ Human infections caused by Microsporum gypseum are very rare. However, the incidence of Microsporum gypseum has noticeably increased in the last 20 years. ${ }^{2}$ Georg has ${ }^{3}$ reported that Microsporum gypseum a low infectivity and only unusually rare strains are able to establish infection. However, previous workers from India and other parts of the world have reported the isolation of Microsporum gypseum from a case of extensive dermatophytosis in an HIV parient in Madras.

\section{Case history}

A 37 year old male patient belonging to a middle income family was admitted in the Government Hospital of Thoracic Medicine, Tambaram, Madras for the treatment of tuberculosis of the lung. He later proved

\footnotetext{
* Department of Microbiology, Dr. ALM PGIBMS, Taramani, University of Madras-113.

t Government Hospital for Thoracic Medicine, Tambaram, Madras-45.
}

to be positive for HIV infection both by ELISA and Western blot technique. The patient was identified as a case of Full-blown AIDS (from June 1994) according to the norms laid down by WHO (1985). His CD4 and CD8 counts were 293 and 709 respectively. He was on treatment with cotrimoxazole for Pneumocystis carinii infection. At the time of our examination he had highly erythematous, non-pustular, circinate lesions which were pale pink in colour, suggestive of dermatophytosis on both his arms, legs, back, waist, face and ear pinna. The patient did not complain of itching. Clinical history revealed that the lesion had become extensive in five days after it was first noticed as a small circinate lesion on the forehead.

\section{Mycology}

Skin scrapings were taken from the active margin of the lesion from the legs, back, arm and forehead using a sterile scalpel after cleaning the infected site with $70 \%$ alcohol. One part of the scraping was examined directly with $20 \% \mathrm{KOH}$ for the presence of fungal elements (Figure 1). The other part of the scraping taken from each site namely leg, back, arms and forehead was inoculated on Sabouraud's dextrose agar slants in duplicate. The slants were incubated at $26^{\circ} \mathrm{C}$ for 21 days. 
$\mathrm{KOH}$ preparations of skin scrapings taken from all the four different sites showed the presence of fungal hyphae and arthroconidia. Fungal growth was observed on the 5th day of inoculation in all the Sabouraud's dextrose agar slants. Initially the fungal colony appeared to be powdery to granular, pale white in colour and later the colony became powdery and buffy. The reverse of the colony was orange yellow. On microscopic examination, numerous 5-7 celled spindle shaped macroconidia with rough margin were seen. Few microconidia were also seen.

\section{DISCUSSION}

Human infections caused by non-anthropophilic dermatophytes have been reported by several workers. ${ }^{6}$ However, human infections caused by Microsporum species are seldom seen in India. ${ }^{4,7}$

In the present study, we have isolated Microsporum gypseum from an extensive case of dermatophytosis in an HIV patient in Madras. Though the lesion was erythematous, the patient had reported no itching of the lesion. Extensive infections caused by non-anthropophilic dermatophytes especially the geophilic dermatophytes such as Microsporum gypseum is not common. Aslop and Prior ${ }^{8}$ suggested that the low infectivity of Microsporum gypseum could be reason for its rare occurence in human infections. ${ }^{3}$ Strains of low virulence may increase in pathogenicity when suitable opportunities for infection occur. ${ }^{9}$ In the present case, immunomodulation due to HIV infection have provided an ideal condition for the organism to cause infection. The CD4 and CD8 count of the patient was in the ratio of $1: 2$, suggesting impaired immunity. High incidence of dermatophytosis in immunocompromised hosts such as patients with diabetes, atopy and patients undergoing long term steroid therapy have been reported. ${ }^{10}$ The absence of itching and the peculiar manifestation of the disease might be due to immunosuppression due to HIV infection. The extensive manifestation of the disease is reported to have occured in 5-7 days. The rapid spread of the disease can also be attributed to the immunocompromised condition. It has been well established that nonanthropophilic dermatophytes produce more severe lesion due to the differences in the host and adaptability of the organism. We report the isolation of Microsporum gypseum from a case of primary infection with extensive, erythematous, non-scaly, non-pustular circinate lesions devoid of itching. Immunosuppression due to HIV infection might have lead to the peculiar manifestation of the disease produced by a geophilic dermatophyte.

\section{REFERENCES}

1. Ajello L. Natural history of the dermatophytes and related fungi. Mycopath Mycol Appl 1994;53:93-110.

2. Alteras I. Tinea capitis by Microsporum gypseum. Mycopath Mycol Appl 1972;47:129-34.

3. Georg LK. Epidemiology of the dermatophytosis, source of infection, modes of transmission and epidemiology. Ann Y Acad Sci 1968;89:69-79.

4. Ranganathan S, Thangam Menon, Selvi SG, Kamalam A. A survey of dermatophytosis in Madras. Biomedicine 1982;14(1):11-3.

5. Allred BJ. Dermatophyte prevalence in Wellington, New Zealand. Sabouraudia 1982;20:75-7.

6. Rippon JW. Dermatophytosis and Dermatomycosis. Pathogenic fungi, and pathogenic actinomycetes. Philadelphia: W.B. Saunders. 1982:154-248.

7. Mohapatra LN. Study of medicinal mycology in India - an overview. Indian J Med Res 1989;89:351-61.

8. Aslop J, Prior AP. Ringworm infection in a cucumber greenhouse. Br Med J. 1961;1:1081-3.

9. Philpot CM. Some aspects of the epidemiology of Tinea. Mycopath 1977;62:3-13. 